\title{
HOSPITALITAS KRISTEN DALAM MENGHADAPI KEKERASAN TERHADAP ANAK SEHINGGA TERJALIN KERUKUNAN ANTARA ANAK DAN ORANG TUA. SRI YULIANA SALILI
}

\author{
Institut Agama Kristen NegeriToraja \\ Sriyuliana475@gmail.com
}

\begin{abstract}
:
This paper describes how violence against children is avery frequent part of every child's life. Then this paper will examine the impact of the causes of violence against children that occur in Indonesia. Where this paper will show how a family will create harmony in the family (hospitality). So that in violence against children, families need to know how to educate their children and love their children without quickly bursting out with anger towards children but where the family is able to create harmony in the family and a good relationship will be established in the face of violence so that in this case the family is responsible for facing the problem of violence against children.
\end{abstract}

Keywords: hospitality, parent-child relationship, violence, parent-child harmony.

\begin{abstract}
Abstrak:
Tulisan ini memaparkan tentang bagaimana kekerasan terhadap anak merupakan sebuah bagian yang sangat sering terjadi didalam kehidupan setiap anak. Kekerasan ini menjadi salah satu fenomena dijumpai dikalangan masyarakat maupun keluarga. Maka dengan tulisan ini akan meliti dampak dari penyebab kekerasan terhadap anak yang terjadi di Indonesia. Dimana tulisan ini akan memperlihatkan bagaimana keluarga yang akan menciptakan adanya kerukunan di dalam keluarganya (hospitalitas). sehingga dalam kekerasan terhadap anak keluarga perlu tahu bagaimana mendidik anaknya dan menyayangi anaknya dengan tidak cepat meluapkan amarah terhadap anak tetapi dimana keluarga mampu menciptakan adanya sebuah kerukunan dalam keluarga dan akan terjalin hubungan yang baik dalam menghadapi adanya sebuah kekerasan sehingga dalam hal ini keluarga bertanggung jawab dalam menghadapi masalah kekerasan terhadap anak.

Kata Kunci: hospitalitas, hubungan Orang Tua-Anak, kekerasan, Kerukunan Orang Tua-Anak.
\end{abstract}




\section{Pendahuluan}

Kasus kekerasan terhadap anak diindonesia akan naik setiap tahunnya dan dapat dilihat adanya 120 kasus kasus kekerasan yang terjadi baik secara fisik maupun psikis. Dan dijelaskan bahwa kekerasan terhadap anak sangat marak terjadi baik itu terjadi dirumah maupun disekolah. Menurut hasil riset KPAI, menguraikan bahwa kekerasan yang sering terjadi terhadap anak itu sering terjadi dalam keluarga. Dan nyatanya kekerasan terhadap anak di Indonesia sangat memprihatinkan dari hal tersebut dibutuhkan sangat perhatian dari pemerintah dan berbagai masyarakat dan orang tua.

Kekerasan terhadap anak sering terjadi karena adanya faktor-faktor yang mempengaruhi seperti rendahnya pengetahuan yang dimiliki orang tua, sehingga anak berada dalam situasai yang rentan, kekerasan yang biasanya terjadi pada anak dimulai dengan dicubit, hal ini membuktikan bahwa anak berada dalam masa yang dapat membuat dirinya rentan untuk melakukan sesuatu. Kekerasan terhadap anak ini sering juga muncul karena adanya faktor kemiskinan, anak yang hidup dari faktor kemiskinan itu sering mendapatkan tindakan-tindakan terhadap kekerasan maka perlunya perhatian dari para aparat Pemerintah dan Masyarakat, karena hidup dalam kondisi kemiskinan sangat rentan terhadap tindakan kekerasan.

Sehingga dapat dikatakan bahwa kerentanan anak di Indonesia dapat kita gambarkan dengan apa yang telah nyata, bahwa anak yang sebelum mencapai pada umur 5 tahun yaitu sekitar 500.000 pertahun meninggal akibat terinfeksi sebuah penyakit yang penyakit ini sebenarnya bisa dicegah tetapi karena berawal dari ekonomi yang rendah.

Dan berdasarkan latar belakang yang telah dipaparkan diatas maka telah dilakukan sebuah penelitian tentang faktor-faktor apa yang berhubungan dengan kekersan terhadap anak yang terjadi di Indonesia dan adanya penguraian bagaimana orang tua yang bekerja dan merupakan bagian dari hospitalitas Kristen.

\footnotetext{
${ }^{1}$ Evi widowati dan Widya Hary Cahyati. " Kejadian Kekerasan Terhadap Anak Tenaga Kerja Indonesia," Palstren 12,no. 1 (Juni 2019): 67-69.
} 


\section{Tujuan dan Manfaat}

- Bertujuan untuk menciptakan sebuah terjadinya kerukunan antara orang tua dan anak.

- Hospitalitas Kristen membuat oramng tua dapat melihat keberadaan untuk dapat kembali menjalin hubungan yang baik dengan anaknya.

- Hospitalitas Kristen dapat menjalin hubungan harmonis kembali dengan anak dan orang tua. 


\section{Pembahasan}

Hospitalitas Kristen memiliki sebuah keterikatan dengan ada kasih harus terjalin antara orang tua dan anak sehingga akan menunjukkan sebuah kerukunan dan keharmonisan dalam sebuah keluarga. Hospitalitas adalah suatu cara yang dapat dilakukan oleh orang lain dalam menunjukkan adanya persahabatan, seperti orang tua terhadap anak ketika orang tua tahu cara membina dan mengajar anak dengan baik maka kekerasan dalam sebuh keluarga itu tidak akan terjadi.

Sebagai contoh gereja dapat menciptakan adanya sikap kerukunan, merangkul orang-orang percaya untuk datang kepadanya dengan gereja mampu memperkuat iman dari sebuah jemaat dan membantunya untuk berelasi dengan orang lain. Begitu pun dengan orang tua dan anak harus mampu menciptakan adanya sebuah kerukunan dalam keluarga ketika orang tua mampu merangkul anaknya dengan baik maka tidak akan adanya sebuah kasus kekerasan yang muncul dari orang tua terhadap anak. Kerukunan itu pun dapat diwujudkan dalam keluarga ketika orang tua memiliki kepedulian terhadap anak, terkadang orang tua sibuk dan stress dengan masalah yang ia hadapi dapat mengeluarkan kekesalannya kepada anak dengan cara mencubit atau memukul anak tersebut. Hospitalitas itu dibangun kepada semua orang untuk bisa dapat menjalin kerukunan dan keharmonisan dalam keluarga, disini orang tua harus mampu menjalin hubungan yang baik dengan anak karena anak cenderung mengakui keberadaannya ditengah keluarga maupun masyarakat, sehingga orang tua harus bisa memperlihatkan titik yang bisa membuat anak untuk dapat membangun kerukunan itu. Sebagai contoh dimana orang orang tua memberikan perhatian khusus dengan anaknya, selalu memberikan suasana yang baru terhadap anak sehingga disini anak merasa lebih senang bahwa orang tuanya peduli terhadap dia, maka tingkat kerukunan dan keharmonisan itu akan hadir dalam keluarga tersebut tanpa adanya sebuah kekerasankekerasan yang muncul.

Lingkungan dalam keluarga pun memiliki kecenderungan adanya sikap saling tidak peduli, dimana orang tua terlalu sibuk dengan pekerjaannya dan akhirnya stress akibat dari pekerjaan, tetapi terkadang banyak orang tua yang mudahnya memarahi anak. Orang tua tidak tahu bahwa anak masih dalam tahap belajar dan mempunyai keingin tahuan yang besar, dan orang tua yang tidak memiliki akan pemahaman yang baik terkadang anak yang sangat peka terhadap keingin tahuan dianggap oleh orang tua sebagai anak yang nakal, sehingga orang tua pastinya akan memberikan hukuman kepada anak agar tidak melakukan sebuah kesalahan yang sama. 
Hospitalitas Kristen memperlihatkan bagaimana cara dalam mengekspresikan adanya sebuah sikap kekristenan. Hospitalitas Kristen merupakan sebuah dari ungkapan kasih Allah, dimana semua orang didunia melihat bagaimana orang Kristen telah melakukan hospitalitas Kristen. Dan orang Kristen yang telah mengenal Allah berarti dia telah melakukan hospitalitas Kristen di dalam kehidupannya. Dalam hal ini sifat empati dilakukan agar orang lain dapat merasakan apa yang dirasakan oleh orang lain sehingga dapat mendorong orang tersebut untuk melakukan yang namanya sikap saling menolong agar dapat menciptakan adanya sebuah kerukunan dalam setiap keluarga. Sama hal dengan gereja yang dimana orang Kristen yang dilanda dengan adanya virus corona sehingga jemaat disarankan untuk memiliki sikap yang empati didalam gereja. Karena jika tidak maka dari hal inilah yang tidak dapat mencerminkan adanya hospitalitas Kristen dan akan menimbulkan kekerasan seperti anak terhadap orang tua ketika orang tua hanya melihat anak dari sisi nakal maka hospitalitas itu tidak akan terwujud Dalam situasi yang demikian akan membuat masyarakat untuk saling menjauhi satu sama lain dengan adanya virus covid-19 ini , bahkan dalam kawasan tempat tinggal dan lainnya. Disini dapat dilihat bahwa sifat empati tidak terwujud dalam hal ini sehingga akan muncul pula adanya tindakan-tindakan yang bisa merujuk kepada kekerasan, karena berkurangnya pengahasilan dalam sebuah keluarga sehingga anak yang akan menjadi korban dari hal tersebut, karena penghasilan ekonomi yang makin menurun sehingga orang tua mulai pusing tentang dari mana ia mendapatkan penghasilan seperti duluh dan akhirnya anak menjadi korban kekerasan dalam dalam hal tersebut.

Hospitalitas Kristen dalam hal ini memberikan pencerahan bahwa dalam hal ini memberikan banyak pertimbangan bahwa adanya pertimbangan etis yang diterapkan dimana lebih banyak memberikan sebuah pencerahan kepada pemerintah agar kebijakan-kebijakan itu harus dilakukan agar masyarakat dapat dilindungi dalam situasi tersebut. Sama hal dengan hospitalitas Kristen yang terus memciptakan adanya kerukunan dalam masyarakat dan keluarga. Dimana keluarga harus saling rukun dalam menyikapi sikap tersebut sehingga dengan adanya hospitalitas Kristen dalam masyarakat dapat membuat masyarakat lebih menerapkan adanya sikap saling peduli terhadap sesamaya. Hospitalitas Kristen dalam hal etis memberikan sebuah pemahaman kepada orangorang untuk tetap berada dalam hal yang dianggap baik empati adalah sesuatu yang sangat dibutuhakan sehingga terciptanya sesautu di dalam masyarakat sehingga sikap empati ini dapat membangun dalam hal ini bisa diaktakan bahwa hospitalitas Kristen dapat membangun relasi yang dengan sesama anggota masyarakat dan tidak mengesampingkan adanya hal-hal yang dapat membuat masayarakat atau anggota keluarga menjadi frustasi karena adanya hal-hal yang dapat membuatnya menjadi tidak peka terhadap orang-orang yang memunculkan diri dihadapannya. 
Sehingga hal ini akan menjadi sesuatu yang sangat ditakutkan oleh masyarakat pada waktu itu dengan adanya hospitalitas Kristen dalam kehidupan kita dapat membuat kita menjadi pribadi yang lebih baik dari pribadi-pribadi sebelumnya sehingga dalam hal ini masyarakat dapat melihat kembali yang mana posisi yang mereka anggap untuk dilakukan didalam masyarakat sehingga masayarakat dapat melihatnya dari sudut pandang yang baik begitu pun dengan dampak kekerasan terhadap anak yang semakin marak kasusnya. ${ }^{1}$

\footnotetext{
${ }^{1}$ Yohanes K. Susanto. “Hospitalitas Sebagai Upaya Mencegah Kekerasan Dalam Memelihara Kerukunan Dalam Relasi Islam-Kristen Di Indonesia". Societas Dei: Jurnal Agama dan Masyarakat 2, no. 1(October 2017):308-311.

Daniel, Fajar Panuntun, Eunike Paramita. "Hospitalitas Kristen Dan Tantangannya Di Tengah Covid-19". Jurnal “Harmoni”19, no. 1 (Maret 2020):73.
} 


\section{FAKTOR TERJADI KEKERASAN TERHADAP ANAK DALAM KELUARGA.}

Dengan ini berdasarkan dari sebuah hasil penelitian maka ada beberapa alasan kasus kekerasan terhadap anak dalam masyarakat maupun keluarga antara lain:

\section{- PEWARIS KEKERASAN ANTAR GENERASI}

Terkadang banyak anak yang sejak kecil melihat kekerasan yang sering dilakukan oleh orang tuanya, sehingga ketika dia telah tumbuh dewasa dia melakukan tindakan kekerasan yang sama kepada anaknya. Kemudian dari tindakan kekerasan tersebut akan berdampak pada generasi-generasi berikutnya. Dalam hal ini anak-anak selalu peka terhadap sesuatu yang ia lihat, disini orang tua kerap tidak menyadari bahwa ketika anak selalu dikerasi akan mempengaruhi dampak psikologi pada diri anak. Hospitalitas Kristen memberikan sebuah cerminan bahwa ketika suasana dalam keluarga itu bahagia maka akan menghasilkan sesuatu yang rukun dan terjalinnya suatu keharmonisan yang utuh dalam sebuah keluarga.

Kekerasan terhadap anak dalam keluarga sulit diungkap keruang publik. Seringkali kasus-kasus yang dianggap melanggar batasan atau etika terhadap kekerasan memukul anak baik kaki maupun kepala dari anak sehingga hal itu membuat anak terluka. Masyarakat sering memiliki pandangan bahwa anak harus patuh terhadap orang tua , sangat menyebar luas pandangan ini disalah artikan oleh orang tua.

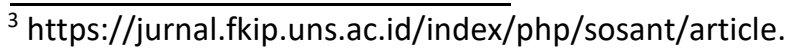


Masyarakat sering memiliki pandangan bahwa anak harus patuh terhadap orang tua, sangat menyebar luas di dalam masyarakat sehingga pandangan ini disalah artikan oleh orang tua. Masyarakat yang selalu menempatkan anak-anak pada golongan rendah sehingga orang dewasa kerap memperlakukan anak-anak sesuai dengan keinginan mereka sehingga anakanak kerap menganggap dirinya tidak memiliki hak apa pun, baik itu dalam hak membela dirinya maupun untuk berbicara. Hospitalitas Kristen memperlihatkan bagaimana adanya tolak ukur yang tidak seimbang antara orang tua dan anak sehingga orang tua lebih cenderung mengambil tindakantindakan yang dianggapnya itu tidak baik, baik untuk anak tetapi tidak menyadari bahwa anak merasa tidak senang dengan perlakuan-

perlakuan seperti itu . hospitalitas Kristen memperlihatkan pula hal-hal yang harus dilakukan orang tua dengan mengubah pola perilakunya untuk menjalin hubungan yang harmonis dengan anak sehingga anak juga dapat melihat adanya suatu kerukunan yang muncul dari keluarga.

Kekerasan fisik merupakan sebuah tindakan yang dapat mengakibatkan terjadinya sebuah kekerasan fisik yang terjadi kepada anak dalam hal memukul kepala, mencubit bahkan membunuh. Orang tua sering kali tidak dapat menahan kemarahannya ketika anak melakukan hal-hal yang salah atau hal-hal yang tidak disengaja oleh anak. Banyak juga orang tua yang memukul anaknya karena anak tidak patuh terhadap apa yang dikatakan oleh orang tua bahkan ketika anak mengalami masalah dengan temannya dengan saling mengejerk bahkan bertengkar, orang tua mulai memarahi anak tanpa bicara baik-baik terlebih dahulu kepada anak apa yang menjadi sehingga anak tersebut bertengkar.

Tetapi disini orang tua hanya meluapkan rasa kesalnya kepada anak, dan tidak tahu bahwa pada saat ini anak masih belajar. Orang tua saat memukul anak terkadang ia tidak sadar akan tindakannya tersebut seperti dari memukul itu anak akan menjadi depresi bahkan hasil dari pukulan itu bisa membekas dan menjadikan anak tidak mau lagi berbaur dengan orang lain bahkan untuk dekat dengan orang tuanya anak tidak mampu lagi, sehingga anak mulai menghindarkan dirinya sendiri dari kedua orang tuanya bukan hanya dengan itu anak akan merasakan adanya depresi yang sangat besar dan akhirnya ia tidak mau lagi berbaur dengan orang-orang yang berada disekitarnya. Adanya juga konflik dalam keluarga baik antara suami dan isteri sehingga terkadang orang tua akan merasa terbebani secara psikologi maupun psikis sehingga orang tua tidak mampu untuk menahan amarahnya dan anak menjadi korban tindakan dalam amarah yang dirasakan oleh orang tua baik itu dalam menghadapi anak.

Sering kali depresi masa lalu yang pernah dihadapi oleh tua terkadang ia tidak melupakan akan hal itu sehingga ia tidak dapat masuk dalam zona nyaman dan sering tidak tidak muda memisahkan antara tindakna-tindakan yang betul dan terlalu berlebihan sehingga terkadang anak sudah tidak dipedulikan lagi dan 
orang tua yang selalu mengingat akan depresi masa lalunya dan anak yang melakukan sesuatu yang mungkin hal kecil, pastinya orang tua akan langsung memarahi anak bahkan langsung mencubit atau memarahi anak. Hospitalitas Kristen dalam hal ini ingin menciptakan adanya hubungan yang rukun antar keluarga walaupun dalam keluarga selalu adanya pendapat yang tidak sama hendaknya dibicarakan dengan baik dan jangan sampai anak menjadi korban tindakan kekerasan dalam permasalahan tersebut. Hospitalitas Kristen ingin juga mengupayakan terjalinnya setiap hubungan di dalam masyarakat maupun keluarga, karena menjelaskan bagiamana kerukunan bahkan sebuah keharamonisan itu dapat tercipta jika adanya sikap saling menyayangi sesuai dalm konteks kekristenan.Hospitalitas Kristen adalah keharmonisan dalam suatu masyarakat dan juga keluarga, hospitalitas Kristen ini juga dapat memberikan sebuah perlakuan yang baik kepada masyarakat. Dimana masyarakat diajarkan dalam bagaimana berkelakuan etik yang baik. Menurut pandangan antropolog bahwa hospitalitas Kristen dapat membentuk adanya kerukunan dan keharmonisan dalam suatu masyarakat maupun keluarga. Dalam hal ini juga menjelasakan bahwa adanya kerukunan, keramahan, dan keharmonisan dalam suatu keluarga dapat menjadikan sebuah persahabatan yang diciptakan dari hospitalitas Kristen. Hospitalitas sebagai wujud dari kasih Allah untuk dunia, dimana orang-orang yang merasakan adanya kasih Allah ia pasati akan memaknainya sebagai wujud dari hospitalitas Kristen antara ia dengan orang lain.

Dengan adanya hospitalitas Kristen dalam kehidupan kita, menjadikan setiap orang lebih dapat menciptakan adanya kerukunan bahkan keramah-tamahan dalam suatu masyarakat dengan mereka tidak akan saling membeda-bedakan antara sesamanya, namun dari adanya hospitalitas Kristen ini hubungan antara sesama manusia dapat lebih menciptakan adanya suasana persahabatan maupun kerukunan ditengah-tengah masyarakat, disini juga sesama manusia dapat menghargai satu sama lain bahkan juga menerima keadaan dari setiap orang dan ini terwujud karena hadirnya hospitalitas Kristen di dalam masyarakat. Hospitalitas juga dikaitakn sebagai bentuk cinta kasih terhadap semua orang dan dari adanya cinta kasih ini mereka akan saling mengasihi sesama manusia sama seperti Tuhan yang mengasihi kita.

Dalam hospitalitas Kristen dijelaskan bahwa setiap orang telah menjadi bagian dari keluarga maupun terjalinnya persahabatan dan kerukunan akan saling mengasihi satu sama lain, menerima orang lain sebagai keluarga dalam hidup kita dan akan terjalin terus sifat saling mau menerima dengan adanya hospitalitas Kristen keluarga maupun dalam masyarakat sudah dapat tahu apa yang menjadi tolak ukur mereka dalam hal untuk saling menciptakan suasana yang harmonis dalam sebuah masyarakat dengan keluarga, tentunya hal ini perlu dilakukan dalam menciptakan adanya persahabatan yang erat antara 
sesama manusia sehingga hospitalitas itu akan tumbuh dari pribadi kita sendiri. ${ }^{1}$

\footnotetext{
${ }^{1}$ Lulu'il, Makmun. "Kekerasan Terhadap Orang Tua Yang Stress". Harkat: Jurnal Media Komunikasi Islam Tentang Gender dan Anak (Februari 2016):119-122.

Daniel, Fajar Panuntun. “ Nilai Hospitalitas Dalam Budaya Longko'Torayan”. In Teologi Kontekstual Dan Kearifan Lokal Toraya,19,2020.
} 


\section{Kesimpulan Dan Saran}

Setelah melihat pembahasan dari junal diatas maka dapat disimpulkan bahwa Hospitalitas Kristen sangatlah berguna didalam kehidupan masyarakat dan keluarga, seperti kekerasan terhadap anakhal ini akan hilang jika keluarga mampu menciptakan adanya kerukunan dalam masyarakat sehingga akan memunculkan relasi dari anak dan orang tua. Hospitalitas Kristen akan mampu memberikan sebuah keharmonisan di dalam keluarga sehingga orang tua yang dari duluh suka memarahi bahkan memukul anaknya itu tidak akan terjadi ketika ia sudah mampu menciptakan kerukunan dalam keluarganya atau mampu menciptakan adanya Hospitalitas Kristen. Kemudian saran dari jurnal ini adalah penulis masih perlu mengembangakan setiap tulisan yang ada sehingga ketika pemabaca melihat jurnal ini dapat menarik hati setiap pembaca. 


\section{Referensi}

\section{Daftar Pustaka.}

Widowati Evi dan Widya Hary Cahyati, "Kejadian Kekerasan Terhadap Kerja Indonesia," Palastren 12,no.1(Juni 2019):67-69.

Susanto, Yohanes K. "Hospitalitas Sebagai Upaya Mencegah Kekerasan Dalam Memelihara Kerukunan Dalam Relasi Islam-Kristen Di Indonesia." Societas Dei: Jurnal Agama dan Masyarakat 2, no.1 (October 2017):308-311.

Panuntun, Daniel Fajar, dan Eunike Paramita. “ Hospitalitas Kristen Dan Tantangannya Di Tengah Pandemi Covid-19. “ Harmoni”19, no.1(2020):73.

Maknum, Lulu'il. "Kekerasan Terhadap Orang Tua Yang Stress.” Harkat: Jurnal Media Komunikasi Islam Tentang Gender dan Anak (Februari 2016):119-122.

Panuntun, Daniel Fajar. “Nilai Hospitalitas Dalam Budaya Longko' Torayan”. In Teologi Kontekstual Dan Kearifan Lokal Toraja,19,2020.

\section{Internet}

https://jurnal.fkip.uns.ac.id/index.php/sosant/article. 

